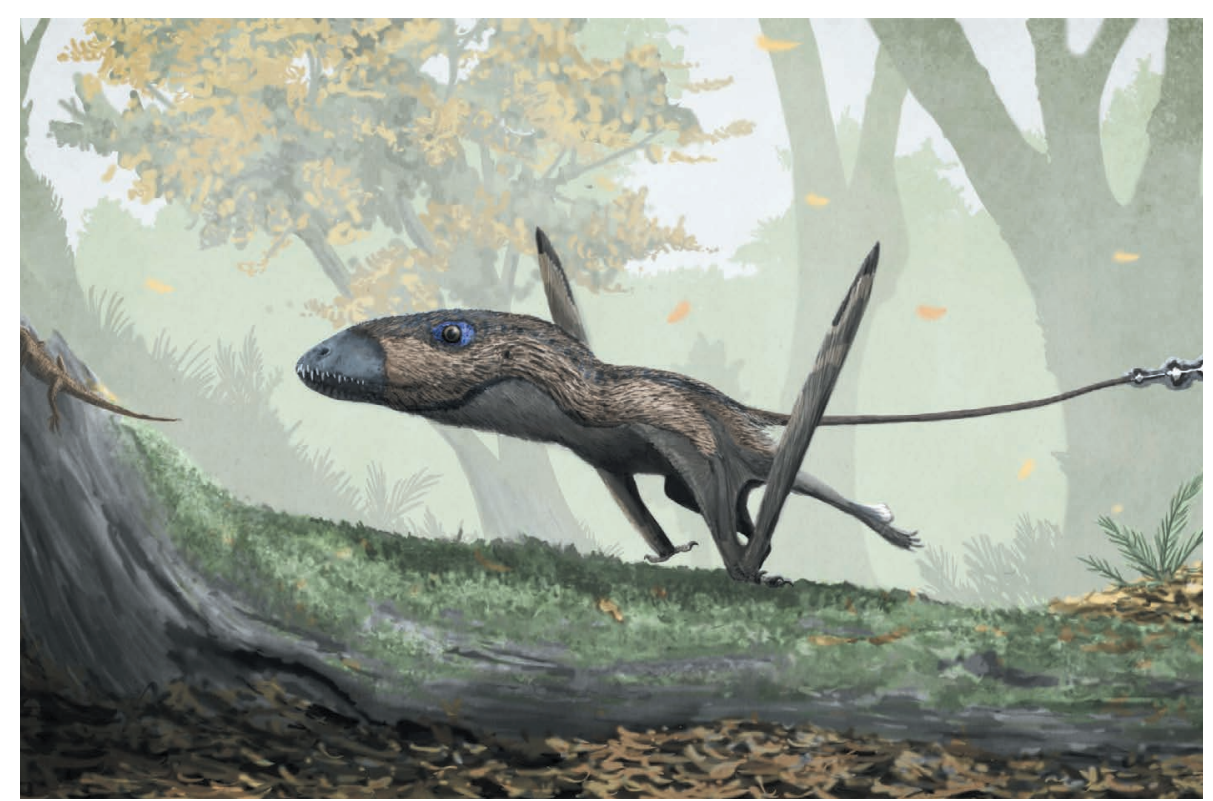

Fossil teeth of Dimorphodon macronyx suggest that it ate insects and small land vertebrates.

PALAEONTOLOGY

\title{
Pterosaur teeth
} reveal ancient diet

\section{Feeding habits of flying reptiles have been much debated.}

\section{BY JOHN PICKRELL}

$\mathrm{M}$ icroscopic scratches on fossil teeth are forcing palaeontologists to rethink some cherished ideas about the diets of pterosaurs - flying reptiles that ruled the skies while terrestrial dinosaurs flourished on the lands beneath them.

Since pterosaur fossils were first uncovered in the eighteenth century, researchers have made assumptions about their eating habits, mostly from indirect clues such as the shapes of their teeth and the environments they lived in. But Jordan Bestwick, a palaeontologist at the University of Leicester, UK, and his colleagues sought more-direct evidence: they performed the first examination of fossilized pterosaur teeth for tiny abrasions caused by food. Microscopic scratches and chips create characteristic surface textures that vary according to an animal's diet, says Bestwick.

The preliminary findings offer new details about the feeding habits of some species, and confirm theories about the diets of others. Bestwick presented the results, which will form part of his $\mathrm{PhD}$ thesis, at the Palaeontological Association's annual meeting in London on 18 December.

One surprise finding in the analysis raised questions about the pterosaur Dimorphodon macronyx, which researchers assumed had hunted fish. The wear and tear on the reptile's teeth suggests that it actually feasted on insects and land vertebrates.
Although pterosaurs existed for 150 million years, complete fossils are relatively rare, and gut contents have been recovered from just four species. That means that most hypotheses about species' diets have been "little more than speculation based on scant evidence", says Bestwick.

$\mathrm{He}$ and his colleagues have so far examined 11 pterosaur species, looking at tooth specimens held at institutions such as the Natural History Museum in London and the Museum for Natural History in Berlin. They used infinite-focus microscopes to create 3D images of tooth wear. They then used statistical methods to look at wear patterns on pterosaur teeth, alongside the teeth of living species of bats, lizards and crocodilians that are known to eat insects or fish and other vertebrates.

Analysis of the pterosaur Rhamphorhynchus reveals wear patterns that are statistically similar to those seen in modern relatives of crocodiles. This suggests that Rhamphorhynchus ate fish, backing up a long-standing hypothesis about the pterosaur's diet, Bestwick says. Wear patterns on the teeth of Pterodactylus, the first pterosaur ever described, in 1784, suggests that it was an omnivore, as some experts had also hypothesized, he adds.

Stephen Brusatte, a palaeontologist at the University of Edinburgh, UK, says the study is one of the first attempts to use a rigorous statistical method to determine what these flying reptiles ate. "This is a great example of how a combination of cutting-edge techniques and careful comparisons to modern species can help us understand how long-extinct animals behaved," says Brusatte.

Steven Vidovic, a vertebrate palaeontologist at the University of Portsmouth, UK, says that complete fossils of pterosaurs are so rare because their light, hollow bones were relatively fragile and unlikely to fossilize. The lack of direct evidence of their diets has often led to researchers making assumptions on the basis of the reptiles' environment, he says. For instance, pterosaur remains are often found in coastal environments, which led researchers to assume that many species ate fish, he says.

Vidovic says the latest analysis will enable palaeontologists to test theories about pterosaurs' diets. "This new method presents a real opportunity to observe the hardness and abrasiveness of the food pterosaurs were consuming, and test hypotheses of ecology," he says. -
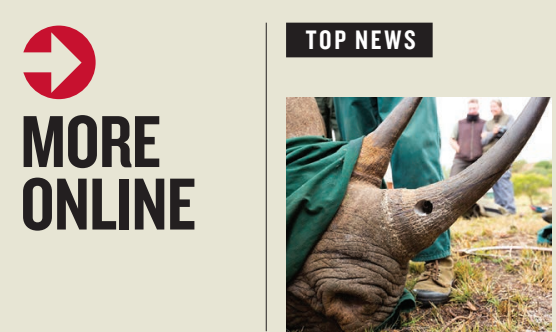

Rhinoceros poachers prosecuted using DNA database go.nature. com/2akgkny

\section{MORE NEWS}

- Long-awaited US report charts course for studies of Earth from space go.nature. com/2cht2rg

- How the immune system could stymie some CRISPR gene therapies go.nature.com/2d9zezy

\section{NATURE PODCAST}

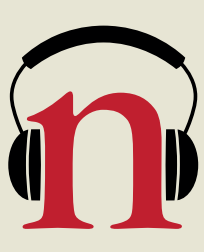

Tabletop physics; what a memory looks like; and conflict's toll on wildlife nature.com/nature/ podcast 